\title{
The Role of Gold In Alchemy. Part II
}

\author{
George B. Kauffman \\ Department of Chemistry, California State University, Fresno, California 93740, U.S.A. \\ The search for the philosopher's stone, the agent for transmuting base metals into gold, \\ laid the groundwork for modem chemistry. The origin, both in time and place, of the stone, \\ which wasknown by innumerable fanciful names, is obscure. Writers disagree in describing \\ itspowers, properties and colour as well as the time required for transmutation. In addition \\ to its transmutatory power, the stone was believed to have the properties of a universal \\ medicine for longevity and immortality (potable gold, aurum potabile).
}

\section{The Philosopher's Stone}

Transmutation, the goal of alchemy, was believed to be achievable by means of the ever-clusive philosopher's stone, or to be more accurate, the stone of the philosophers (lapis philosophorum), which thus became itself the goal of alchemy (Figures 18 and 19). In Read's words,

'The history of science contains no parallel to the quest for the Philosopher's Stone; it contains nothing else as impressive or romantic. The achievement of the Stone was the great and final goal of alchemy' (24, p. 118).

Yet this quest, which was pursued by alchemists for century after century, resulted in knowledge of the physical properties and chemical reactions of an immense variety of natural and artificially prepared substances and laid the groundwork for modern chemistry. According to Justus von Liebig,

'The most lively imagination is not capable of devising a thought which could have acted more powerfully and constantly on the minds and faculties of men, than that very idea of the Philosopher's Stone. Without this idea, chemistry would not now stand in its present perfection ... In order to know that the Philosopher's Stone did not really exist, it was indispensible that every substance accessible ... should be observed and examined' (37, p. 53).

Like many other concepts of alchemy, the origin and place of the idea of the philosopher's stone is obscure. It probably arose in the efforts of alchemists to rationalise their failures to transmute base metals into gold; obviously, some essential, but lacking, ingredient was necessary to effect the desired change (34, p. 46) magically, or in modern chemical terms, catalytically (36). Multhauf states that Zosimos of Panoplis (ca.350-420), the Alexandrian chemist, whom, as we have seen, Multhauf considered 'the earliest writer known to us with certainty to have been an alchemist' $(26, \mathrm{p} .85 ; 36)$, was familiar with the idea of such a substance, which he called 'the tincture' or 'the powder' (xérion), which came down to us through the Arabic into Latin as 'elixir'. In a typical example of alchemical antithetical rigmarole, Zosimos wrote,

$\therefore$. receive this stone which is not a stone, a precious thing which has no value, a thing of many shapes which has no shapes, this unknown which is known of all .... Its kind is one, its species multiple. All comes from the One, and all returns to it .... Here is the Mithriatic mystery, the incommunicable mystery' $(18$, p. 135$)$.

Read likewise dates the idea from Alexandria in the early

NOTE: Part I of this review was published in Gold Bull., 1985, 18, (1), 31-44. The article will be concluded with Part III in the next issue of the journal. centuries of the Christian era $(24$, p. 12), but he also cites a similar belief as common to earlier Occidental and Oriental civilisations (24, p. 6). He believes that 'the father of perfection throughout the world' in the Emerald Table of Hermes Trismegistos refers to the

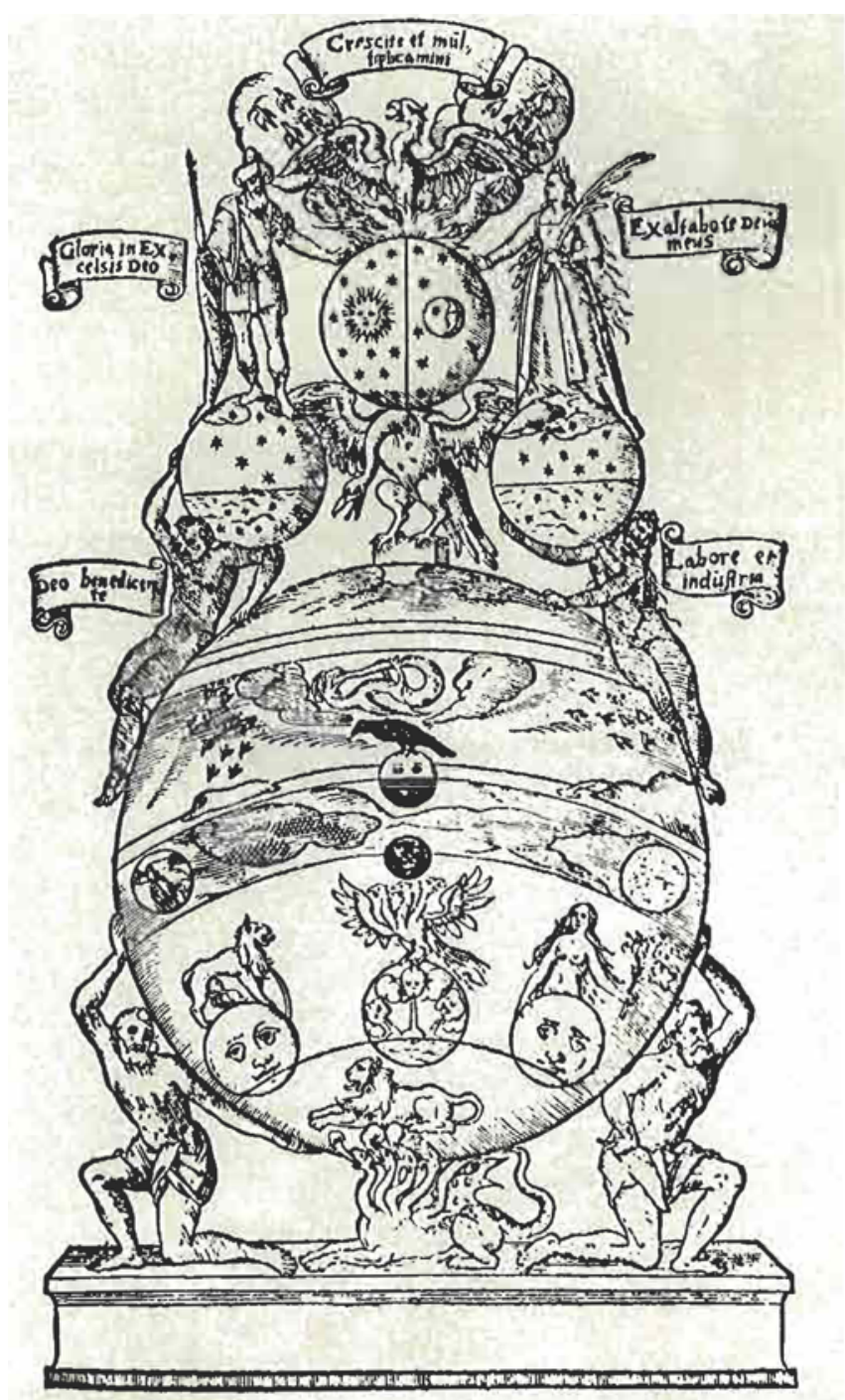

Fig. 18 The Philosophers' Stone, frontispiece from A. Libavius Alchyınia (1606). Deutsches Museum, Munich. After Trenn (178) - see Part III of this review 


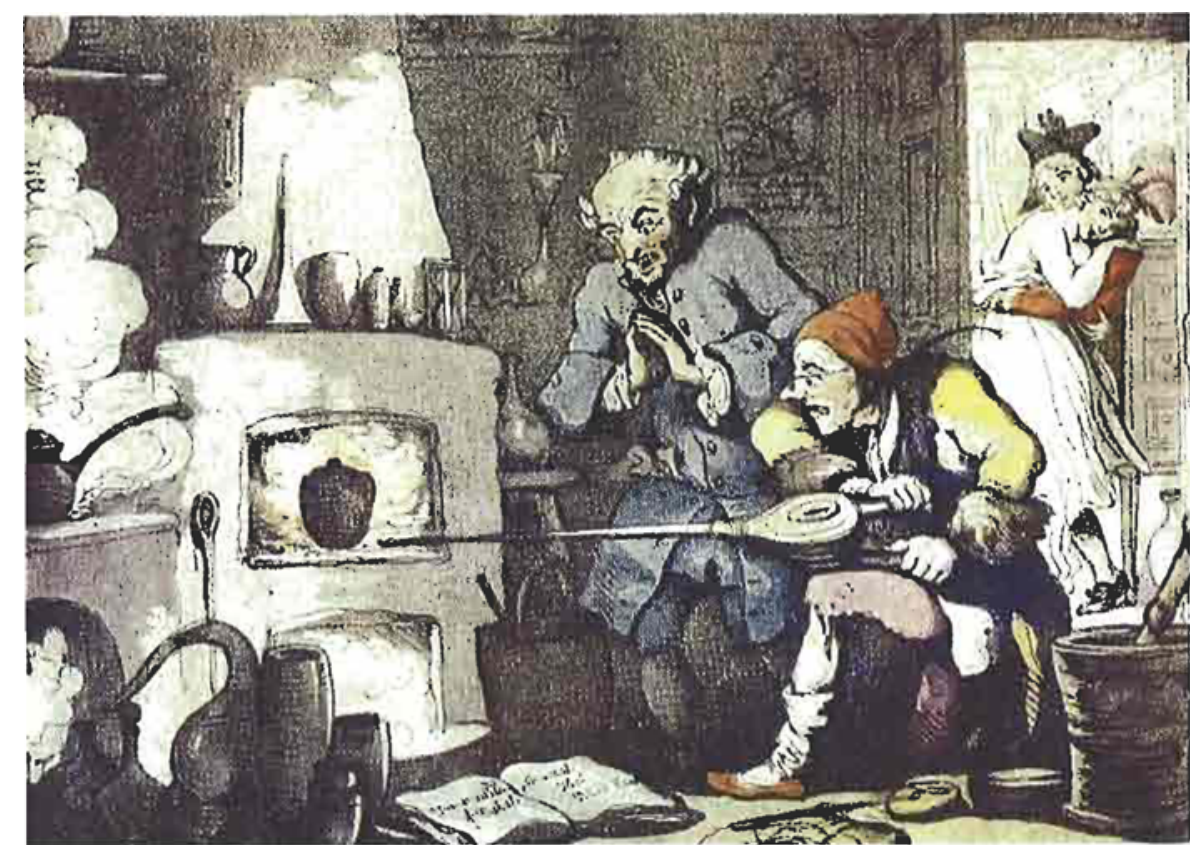

Fig. 19 (left). 'Hocus Pocus' or Searching for the Philosophers' Stone. A painting by T. Rowlandson, 1800 , showing vividly the conditions under which the alchemist worked at the time - the laboratory may well be one of the rooms of the alchemist's home. After Read (145)
Fig. 20 (below left). Symbolic illustration of Saturn, representing lead, being cooked in a bath until the white dove, or spirit, ascends. Descriptions of the Philosophers' Stone, and its role in transmutation, were full of elegant imagery such as the depiction in this figure. After Powell (32)

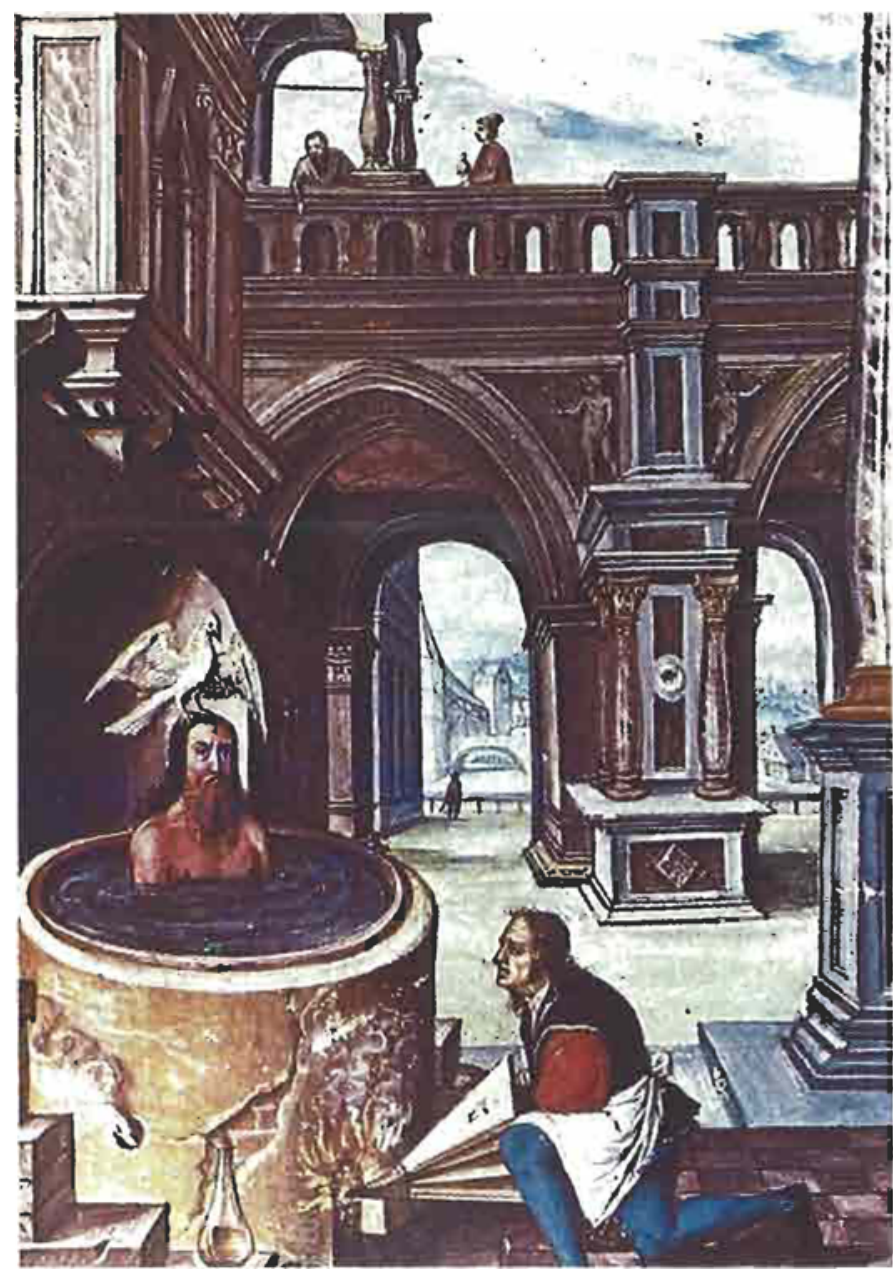

70 philosopher's stone (24, p. 119). On the other hand, Caron and Hutin $(23$, p. 70$)$ state that there is no definite mention of a transmutatory stone until the 13 th century A.D., when it appears in the tradition of the Holy Grail (the cup used by Christ at the Last Supper) as found in the works of the Middle High German poet Wolfram von Eschenbach (ca. 1170-1220), the author of the epic 'Parzifal', the basis for Richard Wagner's last opera, 'Parsifal', and best known to music lovers as a character in Wagner's opera 'Tannhäuser'. The substitution of a stone fallen from heaven for the grail of earlier versions was apparently due to an Islamic influence (100).

The Catalonian, Arnold of Villanova (ca.1235-1311) (101), one of the patron saints of later medieval alchemy, referred to the stone as follows:

$\therefore$... there abides in nature a certain pure matter, which, being discovered and brought by art to perfection, converts to itself proportionally all imperfect bodies that it touches' (102),

while Pernety in 1787 made it central to his definition of alchemy:

'a science, and the art of making a fermentative powder, which transmutes imperfect metals into gold, and which serves as a universal remedy for all the ills of men, animals, and plants' $(51$, p. 17).

The philosopher's stone was known by a variety of fanciful names, e.g. The Powder of Projection, Grand Magisterium, Elixir, Tincture (the Dyer), Universal Essence, Quintessence, Phoenix, Serpent's Brother, Universal Medicine, Yoke of the Egg, Carbunculus, Xit, Basalisk, Stone of the Wise, Bath or Fountain of the King (Figure 20), Blood of the Salamander, Yod He Vav He(the Tetragrammaton or Hebrew name for God), Virgin's Milk, Tall Man with a Helmet, Shadow of the Sun, Serpent Eating His Tail (103), 
Water of Sulphur and Spittle of Lune (18, p. 132; 24, p. 127;34, p. 48). Many terms, e.g. Red Lion or Red Tincture, were derived from the supposed colour of the stone, while others, e.g. Water Stone of the Wise or Sophic Hydrolith, referred to its supposed fluid or mercurial constituent $(24$, p. 127). Pernety gives a partial alphabetical list of about 600 synonyms for either the stone or related materials, ranging from Absemir, Adam and Adrop to Zotichon, Zumech and Zumelazuli (51, p. 272; 104). Indeed, many alchemical writers tried to outdo themselves in devising new names or antitherical descriptions for the stone, which added to the confusion and obscurity already rife in alchemy.

In his 'Brevis Manductio ad Rubinum Coelestum' (A Brief Guide to the Celestial Ruby) (1694), Eirenaeus Philalethes, a pseudonym for an Englishman born about 1620 and believed by some to be Thomas Vaughan (1622-1666)(105), the twin brother of the poet Henry Vaughan, wrote that the philosopher's stone

'is called a stone, not because it is like a stone, but only because, by virtue of its fixed nature, it resists the action of fire as successfully as any stone. In species it is gold, more pure than the purest.... If we say that its nature is spiritual, it would be no more than the truth; if we describe it as corporeal, the expression would be equally correct' (106).

We have already seen how alchemy contained numerous references to religious doctrines and beliefs, and many alchemists believed that the stone was symbolic of Jesus Christ (18, pp. 145-147; 107). This is often combined with the preoccupation with numbers, most closely associated with Pythagoras and the Greek school as well as the devotees of the Jewish Kabbalah (108). For example, George Ripley (1415-1490), Canon of Bridlington, in the prologue to his 'The Compound of Alchymie' drew a parallel between the Christian mystery of the Godhead and the alchemical mystery of the philosopher's stone:

'OUnity in the substance, and 'Trinity in the Godhead .... As thou didst make all things out of one chaos, so let me be skilled to evolve our microcosm out of one substance in its three aspects of Magnesia, Sulphur, and Mercury' (106, p. 139).

Similarly, in 1652 Elias Ashmole relates how an Old English poem endows the stone with a heavenly origin and likens its three constituents to the gifts of gold, frankincense and myrrh brought to Bethlehem by the three Magi (109). The still unidentified Basil Valentine ('Mighty King' or 'Valiant King'), on the other hand, in his famous 'The Triumphal Chariot of Antimony' (1660) depicted it as 'composed out of one, two, three, four, and five,' these numbers indicating, respectively, the one primordial matter, the twofold mercurial substance, the three principles (Tria Prima), the four elements and the quintessence (24, pp. 129, 208).

Another numerical conception of the stone is given in a late (1766) edition of the Polish alchemist Michael Sendivogius' (1566-1646) 'Novum Lumen Chemicum' (110), in which the four elements (earth, air, fire and water) are shown proceeding directly from God; the three principles (sulphur, mercury and salt), from Nature; the two seeds (male and female, Sol and Luna, or sulphur and mercury), from the metals; and the one fruit (tincture), from $\operatorname{art}(24$, pp. 208-209; 111). In his comedy of 1612, 'The Alchemist', Ben Jonson mocked all these elusive descriptions of the stone as follows:

\author{
'Your Lapis pbilosopbicus? 'Tis a stone, and not \\ A stone; a spirit, a soul, and a body: \\ Which if you do dissolve, it is dissolved; \\ If you coagulate, it is coagulated; \\ If you make it to fly, it flieth' (Act II, Sc. 1, Lines 47-51).
}

\section{Properties of the Philosopher's Stone}

We have already seen how the alchemists believed that the philosopher's stone had the power of 'perfecting' metals, i.e., converting base metals into gold. As a consequence of their belief in the unity of all matter, they also regarded this medicine of the metals as also the medicine of man, whereby he too could be perfected. Thus the stone, often referred to as the Elixir of Life or Grand Elixir, was also depicted as a panacea for all human diseases, a rejuvenator and a prolonger of life (24, pp. 121-124; 112), an idea which was familiar in China much earlier than in the West (113). Although the 'Ts'an T'ing Ch'i' of Wei Po-yang, the father of Chinese alchemy, is the earliest written work in any language concerned entirely with alchemy (written ca. A.D. 142), it deals largely with the 'pill of immortality' (24, pp. 7, 38, 121-123), yet Liebig dates this extension of the powers of the stone from only the 13th century A.D. $(37$, p. 78$)$.

To these virtues of the stone Solomon Trismosin added that it also could change ordinary stones into precious stones and soften every kind of glass (114), while Ashmole added additional virtues, maintaining that the stone makes it

'possible to discover any Person in what part of the world soever, although never so secretly concealed or hid, in Chambers, Closets, or Cavernes of the Earth .... It enables man to understand the language of the Creatures, as the Chirping of Birds, Lowing of Beasts, etc.' (109, Prolegomena, p. VI).

Of course, in accordance with the idea of alchemy as a spiritual quest, some scholars have asserted that the philosopher's stone is a symbol of the pursuit of wisdom:

'The subject of the Alchemists was Man, and that in seeking the Philosopher's Stone and the Elixir, they, the Alchemists, did not seek a red powder, nor yet a material remedy, much less the transmutation of the baser metals into gold .... The Supreme Initiation ... is a development of the Soul, and brings out the highest good in man by changing or transmuting the baser passions of man' (115).

The descriptions of the physical properties of the philosopher's stone are as diverse and contradictory as those of its alchemical and mystical properties (18, pp. 135-137; 23, pp. 70-72; 24, p. 127; 112, pp. 29-30; 116). Although it was sometimes described as a liquid, more often it was depicted as a powder - fixed, heavy and with a pleasant odour. In colour it was usually described as red. The 14thcentury alchemist Raymond Lully, or someone writing under his name, called it 'carbunculus' (Latin) or 'escarboucle' (French), meaning a small coal, following Pliny's use of this word. Such a coal, 
however, could assume the colour of the fire, and this Pseudo-Lully claimed that it was first black, then red, then yellow, before reaching 'true whiteness'. He thought that it could assume any colour in the universe before attaining its final state, but like Albertus Magnus ( $c a$. 1200-1280) (116a), he believed that its red colour lay hidden beneath its whiteness, and between red and white it possessed a persistent ashen tint which shone 'like the eyes of fishes' and 'coagulated at the circumference'.

Paracelsus stated that the stone was the colour of a ruby, was transparent, flexible and yet broke like glass. Berigard of Pisa (a French nobleman named Claude-Guillaume de Berigard, who taught physics in Pisa during the 17 th century) claimed that it was red - 'the colour of the wild poppy' and smelled like 'scorched sea salt'. Van Helmont wrote that 'it had the colour of powdered saffron

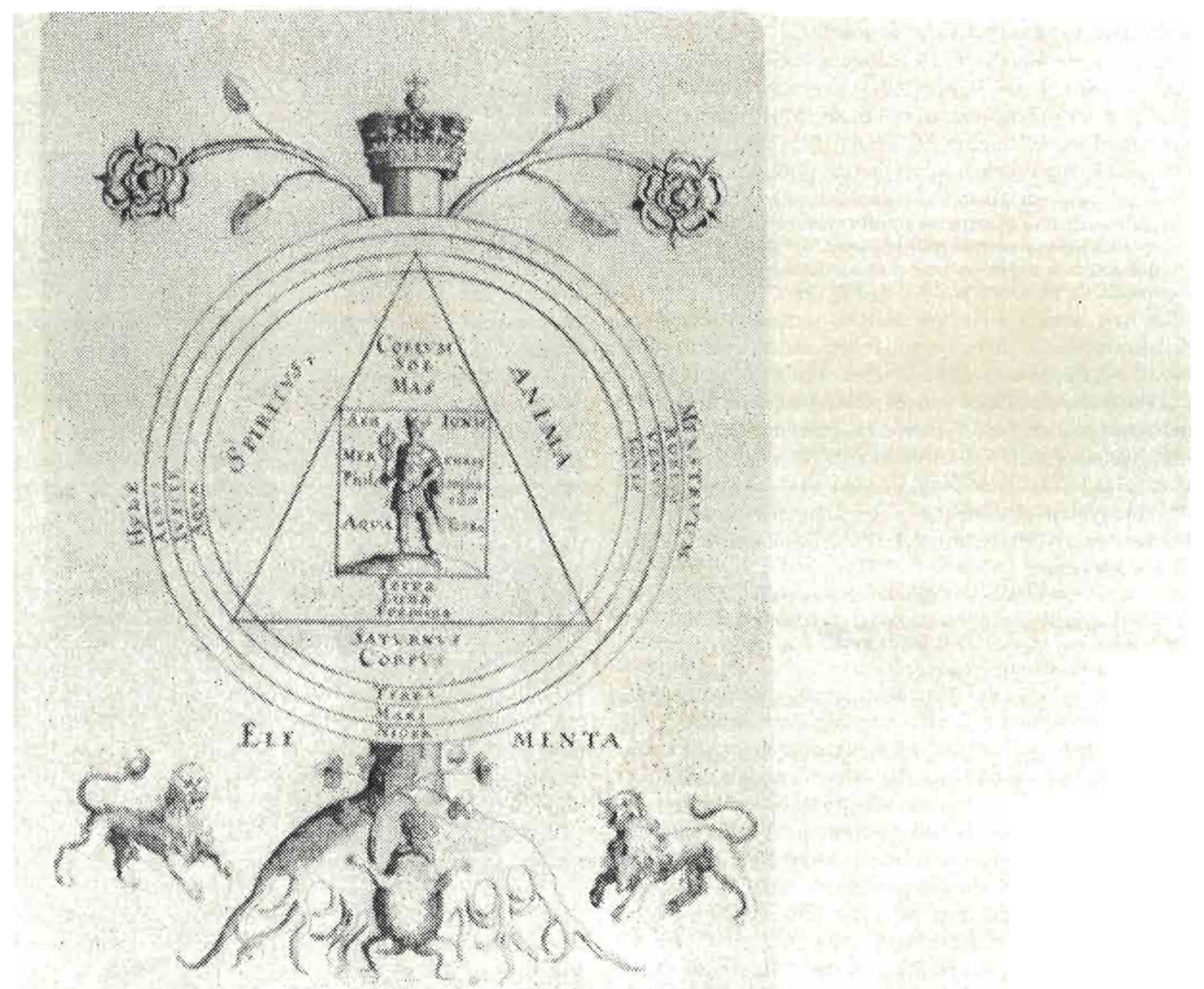

Fig. 21 Representation of the Alchemical Tree, showing the symbols of Transmutation by Mercurius Redivivus (1630). After Coudert (33) 
and was heavy and brilliant like bits of glass'. In describing an alleged transmutation of lead into gold at the Hague on December 27 th, 1666 Johann Friedrich Helvetius (1631-1709) stated that he had examined the stone and found it to be the colour of pale sulphur (20, pp. 157-164; 105, Chap. XX; 68, pp. 211-213; 117). All these inconsistencies were summarized and resolved by the Arabic alchemist Khalid who claimed,

'This stone contains within itself all colours. It is white, red, yellow, skybluc, green' $(23$, p. 72$)$.

To add to the confusion, two forms or degrees of perfection of the philosopher's stone were often distinguished; that for transmuting base metals as far as silver (The Simple Magistery or Little Work) was said to be white, while that for transmuting base metals into gold (the Grand Magistery, Great Work, or Work of the Sages) was said to be red (112, p. 30). The Great Work and Little Work were often symbolized by the sun-tree and the moon-tree, respectively (Figure 21) (118).

\section{Preparation of the Philosopher's Stone}

According to a statement dated 1526, the philosopher's stone 'is familiar to all men, both young and old, is found in the country, in the village, in the town, in all things created by God; yet it is despised by all. Rich and poor handle it every day. It is cast into the street by servant maids. Children play with it. Yet no one prizes it, though, next to the human soul, it is the most precious thing upon earth, and has power to pull down kings and princes. Nevertheless, it is esteemed the vilest and meanest of earthly things' (106, Vol. 1, p. 180).

This supposedly ubiquitous occurrence has sometimes been cited as a reason for the cryptic directions usually given for the stone's preparation. The innumerable recipes for the preparation and use of the philosopher's stone abound in mystical language and a great variety of materials and operations, and they show little agreement with each other. A typical example is the well known recipe attributed to Lully and reproduced by George Ripley:

'To make the elixir of wisdom, the philosopher's stone, it is necessary to take the mercury of the philosophers and calcine it until it turns into the green lion; and after it has undergone thischange thou must calcine it more and it will change into red lion. Digest this red lion on a sand bath with sour spirit of grapes, evaporate this product and the mercury will become a sort of gummy material which can becut with a knife: put this gum into a sealed cucurbit and carry out its distillation slowly. Collect separately the liquors which will appear of diverse nature. Thou wilt obtain an insipid phlegm, then the spirit and some red drops. Cymmerian darkness covers the cucurbit with its dark veil and thou wilt find in the inside a true dragon which eats its tail. Take this black dragon, break it on a stone and touch it with a red-hot char: it will enflame and, taking on a glorious pale yellow colour, it will reproduce a green lion. Make it swallow its tail and distil the product anew. Lastly, rectify carefully, and there will appear before thee fiery water and human blood' (107).

The French chemist Jean-Baptiste Dumas (1800-1884) has explained the recipe as follows:

'The mercury of the philosophers was lead. When lead is calcined the metal oxidizes and turns into massicot (lead monoxide or litharge) which

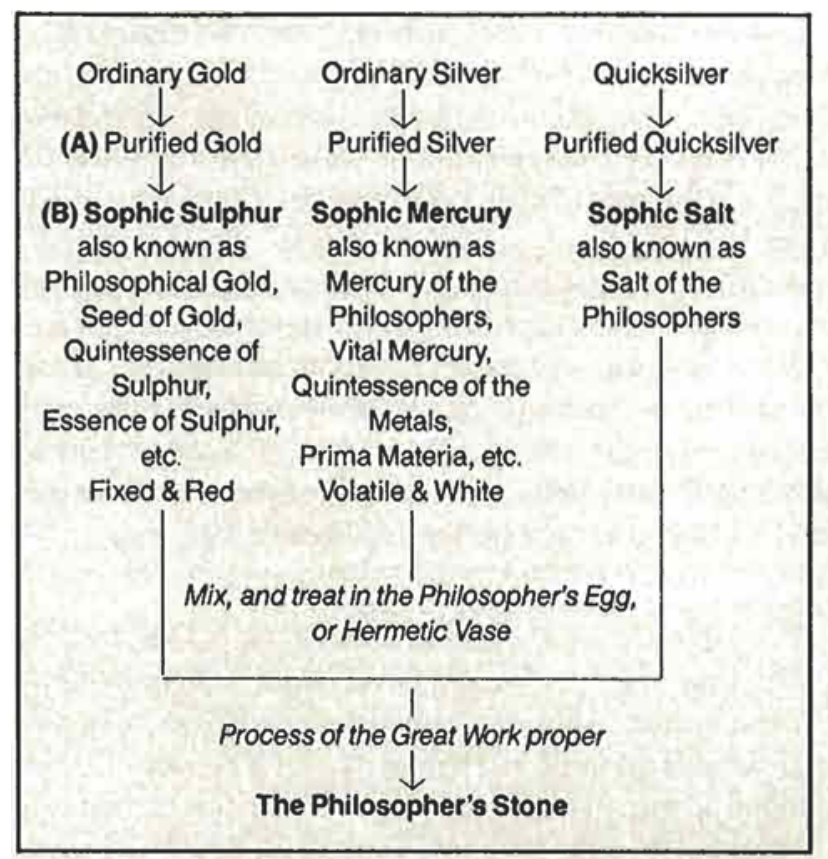

Fig. 22 Diagrammatic representation of a simple scheme for preparing the Philosophers' Stone: (A) Primitive, and (B) Proximate materials of the Great Work. After Read 'Prelude to Chemistry,: an outline of alchemy, its literature and relationships', the MIT Press, Cambridge, U.S.A.

is the green lion. If the calcination is continued, the massicot changes to minium (lead tetroxide) which is the red lion. When the acid spirit of wine of vinegar is added, the lead oxide dissolves and when the liquor is evaporated there is left a gummy mass of lead acetate. The distillation of the lead acetate gives various products, particularly water charged with acetic acid and pyroacetic spirit or acetone accompanied by a little brown or red oil; these are the red drops. The residue which is left is finely divided lead dark grey in colour which suggests the cymmerian darkness. This residue when touched with red-hot char ignites and changes to massicot of which a portion mixed with the distilled liquor combines by degrees with the acid and passes into solution. This is the black dragon which bites and swallows its tail. In distilling anew we obtain acetone which is the fiery spirit and a red-brown oil very difficult to separate. This is the human blood of the alchemists, the elixir sought. It is red, the predestined colour, and possesses the property of reducing and precipitating gold from its solutions' $(107,119)$.

Read gives a diagrammatic summary (Figure 22) of the preparation of the philosopher's stone intended to be regarded as 'a reduction to its simplest terms of one of the many schemes of transmutation which are shadowed with varying degrees of unintelligibility, deliberate or involuntary, in alchemical literature' (24, pp. 131-133). The first purification (gold by fusion with antimony, silver by cupellation, and quicksilver by distillation) yielded the so-called 'primitive materials' $(A)$ or remote matter of the stone. Further secret operations were carried out to obtain the 'proximate materials' (B); in the course of these processes the 
purified gold was usually dissolved in aqua regia (hydrochloric + nitric acids) and the purified silver in aqua fortis (nitric acid). The 'proximate materials' were treated in the sealed Vase of Hermes or Philosopher's Egg (Figure 6 in Part I) according to the elaborate routine of the previously mentioned twelve steps of the Great Work, which was believed to yield the philosopher's stone if carried out under the proper astrological conditions. According to some authorities, it was absolutely necessary that the philosopher's stone be enveloped in wax to produce a transmutation $(23$, p. 72$)$.

Some alchemists performed these operations in a so-called 'cosmic furnace', pictured as a microcosm with its own zodiac, seasons and poles (19, pp. 372-373). In Jonson's play 'The Alchemist' Subtle considers lunar influences on the Great Work:

'How is the moon now? eight, nine, ten days hence,

He will be silver potate; then three days

Before he citronise; some fifteen days

The magisterium will be perfected' (Act III, Sc. 2, Lines 175-178).

The time required for the Great Work varied according to different authors. Although some alchemists likened their work to the creation of the worlu in seven days (possibly because of a mystical relationship with the seven metals and seven heavenly bodies) and therefore believed the work could be accomplished in seven days, most time estimates are given in terms of years (24, pp. 153-154). For example, as of 1969, the modern alchemist Armand Barbault had devoted more than a dozen years to the Great Work but still had not yet completed it (31).

\section{Potable Gold}

Since gold, the metal that does not corrode, symbolizes immortality, the use of gold in medicine has continued from the time of the ancients down to the present day $(11, \mathrm{pp} .44-45,82-84$; 120). As we have already seen, the idea of an elixir of life, closely associated with the philosopher's stone, probably originated in China, where the preparation of a liquid gold believed to produce longevity or immortality was a primary goal of Chinese alchemy ( 5 ; 33 . Chap. $7 ; 38 ; 80 ; 112 ; 121)$. The Hindus also associated medicinal gold with the prolongation of life (122).

Among the Chinese the two most important ingredients of the elixir of immortality were cinnibar $(\mathrm{HgS})$ and gold. According to Ko Hung ( $c a$. A.D. 281-361), the Taoist alchemist and philosopher and the systematizer of Chinese alchemy (5),

'The volumes I have studied must number in the thousands; yet there was not one amongst them that did not insist that reverted cinnabar and Potable Gold were the things of the highest importance. These two, it seems, mark the peak of the divine process leading to geniehood. If taking them does not make one a genie, then genii have never existed' (86, p. 68).

Like the Western alchemists, the Chinese compared the durability of gold and the much sought immortality of the body. In the words of Chang Yin-Chu (8th century A.D.),

'The ancien ts said if one ingests gold one will be like gold. The nature of gold is endurance and resilience. When heated it does not crack or soften, when buried it does not rot [rust], when placed in the fire it will not burn. Hence it is a medicine which can make man live [forever]. After taking gold the skin will nor wrinkle, the hair will nor go white, and one will neither be affected by the lapse of time or disturbed by ghosts and spirits. Hence there will be longevity without end .... Gold is the essence of the sun. It is the prince among the substances [used in the elixir]. After taking gold one can communicate with the immortals, and enjoy a lightness of the body' (123).

Since Chinese alchemists believed that the gold which they made was different from and superior to naturally occurring gold, they were unconcerned whether or not their gold passed the various tests used to distinguish between real and counterfeit gold. Thus they continued to believe in transmutation long after reliable tests for gold had been devised (33, p. 173).

Among the recipes which Ko Hung gave for gold elixirs, the following is typical:

'Prepare three pounds of the skin and fat from the back of a hog and one quart of strong vinegar. Place five ounces of yellow gold in a container and cook over an earthen stove. Dip the gold in and out of the far one hundred times; likewise in vinegar. Take a pound of this gold, and you will outlast all nature. Take a half a pound, and you will live to 2000 ; five ounces to 1200 . It may be taken in any amount, but it must be made on lucky days to be miraculously effective' $(86$, p. 198).

Arnold of Villanova, a believer in astrology and an advocate of the use of gold in medicine, wrote of the 'king of metals':

'It owes its perfection to the unique and admirable balance of elementary constituents and virtues therein. In addition, it harbours specific virtues which are due to celestial influence. In its stability and permanence, gold is itself like a star of heaven. Though an object composed of elements, it is unalterable, insoluble, incorruptible - a miracle of nature. It helps vision, and above all, cleanses and clears the substance of the heart and the fountain of life' (124).

Amold recommended the medical use of gold in a form that could be consumed internally, i.e., as potable gold (aurum potabile). The alchemists, who had long believed that the method for making gold would be found through a method of destroying it, believed in the Latin saying, 'Facilius est aurum construere quam destruere' (It is easier to make gold than to destroy it). They thought that if the indestructible could be destroyed, the intransmutable could be transmuted $(20, \mathrm{p}, 167)$. Since the long-sought royal solvent for gold - aqua regia - was not prepared by Pseudo-Geber (125), until the late 13 th century by adding sal ammoniac (ammonium chloride) to aqua fortis $(126,127)$. Arnold was not familiar with this solvent. Hence his favourite recipe for potable gold, which, in a process similar to Ko Hung's recipe above, involved quenching a heated gold plate in a container of wine four or five times, contained no gold (128).

Paracelsus recommended potable gold as a cure for various ailments, e.g. melancholy, because it 'made one's heart happy' (129). He believed that it was particularly good for heart disorders because both gold and the heart are ruled by the sun (130). Since he is not very clear in his directions for preparing potable gold (131), it is not clear whether or not it contained any gold (22, p. 315).

Most of the potable gold preparations (German, Trinkgold) made through the centuries seem to have been gold sols or colloidal 
gold (10, pp. 554-560; 132-134). By the early 17 th century they were so well known as to be mentioned no less than five times in Robert Burton's famous compendium 'The Anatomy of Melancholy' (1621) (135), e.g.

'Tobacco, divine, rare, superexcellent Tobacco, which goes far beyond all their panaceas, potable gold, and philosopher's stones, a sovereign remedy to all diseases' (Part 2, Sect. 4, Memb. 2, Subs. 2).

By this time the use of such remedies had fallen into disfavour, for according to Burton,

'Erastus concludes their Philosophical Stones and potable gold, \&c., to be no better than poison, a mere imposture, a nothing' (Part 2, Sect. 4, Memb. 1, Subs. 4).

Medicinal colloidal gold preparations were made by Johann Conrad Creiling (1730), Valentin Krautermann (1717), Georg Ernst Stahl, originaior of the phlogiston theory (1744), and George Wilson (1631-1711) (136, 137). According to Wilson's contemporary, Nicolas Lémery,

'their Aurum porabile, ... which they sell at so dear a price, is commonly nothing else but a tincture of some Vegetable or Mineral whose colour comes near to that of gold... This same cheat of theirs is none of the least that they use to get by, for in point of Medicins, abundance of people prove extreme credulous' (138)

In the same vein Étienne François Geoffroy (the Elder) (1672-1731) concluded,

'that the most valuable and most precious of all metals is the most useless in Physick except when considered as anAntidote to Poverty' (139).

Even today potable gold is occasionally encountered; Goldwasser, a liquor with tiny flakes of suspended gold, is still drunk today (33, p. 174). In 1971 S. Mahdihassan of Karachi, Pakistan described and presented electron microscope pictures (7500 $\mathrm{x}$ magnification) of three alchemical preparations of colloidal gold sold in India and Pakistan (140). According to him,

'Simples, or individual drugs, be it a herb, like Soma, a mineral, like red-ochre, or a metal, like gold, were assumed to contain a quantum of soul as their active principle ... . The idea of each and every substance being endowed with soul was initiated by Animism. When Dualism came later on ..., every thing now became dual-natured with soul as a whole, a mixture of a male-soul and a female-soul, their ratio differing from case to case .... But if a metal and a herb be calcined together, at a critical temperaturc, differential heating would drive away their weaker souls, leaving only the stronger ones behind. The resistant souls would then be the male-soul of the herb and the female-soul of the metal ....

The powerful pair of souls would then fuse as equals into unity, to constitute a hermaphrodite soul .... When such a herbo-metallic complex ... is taken as a drug, the accepting system never lacks the presence of soul and is therefore bound to become everlasting: thus man can become immortal. When the same substance is seeded into mercury the latter becomes everlasting as metal which is gold. But the resultant gold is also the carrier of an ever-growing soul so that the same transferred into a porful of mercury, in turn, changes the latter into gold. Thus alchemical gold, like the original herbo-mineral substance, is a hermaphrodite by constitution and a ferment by function .... Thus whereas ordinary gold used, as a Simple, recommended by Animism, would prolong life in the long run, alchemical gold could do all that at once, as a single dose drug of immortality' (140).

Mahdihassan claimed
'That the special technique of alchemy consisted in bringing about a herbo-metallic complex, with a herbal soul transferred to a metallic body, can be supported by documentary evidence' (140),

and he stated that,

'the first preparation the alchemist succeeded in making was a herbometallic complex and that every alchemical preparation must contain an ever-increasing soul as the active principle.... The next preparation was alchemical gold ... made by mixing herbo-metallic complex with a metal or mexcury, but also by taking ordinary gold and treating it with a plant juice so that revived gold becomes ferment-gold' (140).

He also gave directions for two colloidal gold preparations involving the trituration or calcination of herbs with gold leaves or gold filings, respectively (140).

Closely related to colloidal gold are preparations used to produce gold ruby glass (141). In his 'Alchymia' (1595) Andreas Libavius (ca. 1540-1616) describes the use of gold solutions to produce a red colour in glass $(10$, pp. $564-568 ; 13$, pp. $702-710 ; 126$, Vol. 4, pp. 216-220; 142). Another form of colloidal gold is the so-called 'purple of Cassius', prepared by Glauber in 1659, a quarter of a century before Cassius did (11, Teil 1, pp. 92-94; 12, p. 217; 13, pp. 710-711; 20, p. $220 ; 143 ; 144)$. Fulminating gold, supposedly first prepared by Basil Valentine (107), was also used in medicine (11, Teil 1, pp. 94-98; 107; 120). Today, gold compounds, e.g. sodium tetrachloroaurate (III) and disodium aurothiomalate, are used in the treatment of rheumatoid arthritis (120).

\section{Alchemical Transmutations}

Although transmutation has not been the only concern of alchemists down through the ages, it was still the fundamental goal of the venerable proto-science. Since a mere listing of all alleged cases of transmutation would fill an entire volume, only a short list of some of the better known and better documented cases will be given, together with references, which the reader may consult for details. Many of these accounts read like fairy tales or mystery stories, involving mysterious strangers who perform their miracles and then disappear forever.

Probably the book discussing the largest number of transmutations is Kurt Karl Doberer's popularly written 'The Goldmakers' (20), which contains more than fifty short accounts of alleged cases arranged chronologically. Stephen Henry Emmens (2), the 19th-century Irish-or English-born alchemist who migrated to the United States, devotes about a third of his book 'Argentaurana' (146) to 'The Reasonableness of Transmutation', primarily as a prelude to his own extravagant claims. In 'Enigmas' (147) Rupert T. Gould presents eightstories of transmutation, some in considerable detail, ranging in time from 1618 to 1925. In Chapter 2 of his book 'Alchemy Rediscovered and Restored' (148) Archibald Cockren describes his preparation of the philosopher's stone but not in terms that have any meaning to us. In his first chapter he discusses in varying detail a number of transmutations by others. In addition to thumbnail sketches of various transmutations, Caron and Hutin (23) describe several fraudulent 
transmutations and the means used to perpetrate them. In Chapter 13 of his book 'The Alchemists' (21) F. Sherwood Taylor presents three detailed stories of transmutations. We must also not fail to mention John Read's profusely illustrated books $(24,111,145)$, in which he combines meticulous scholarship with graceful, imaginative writing.

A mong the most interesting of the many tales of transmutation are the following, in approximately chronological order, with the date of the alleged transmutation given when available:

1. Zosimos, called the Panopolitan or the Theban (3rd or 4th century A.D.) (20, pp. 25-31; 22, pp. 162-165).

2. Raymond Lully (1235?-1315)(20, pp. 49-53; 30, pp. 67-71; 68, pp. $113-119 ; 105$, pp. $66,69,85,98,120,131,132,193,196,342$; 112, pp. 47-49).

3. Nicolas Flamel (1330-1418) and his wife Perrenelle - probably the most popular and detailed story of transmutation, 1382. Flamel claimed to have learned the art of transmutation from a manuscript of Abraham, the Jew. He acquired great wealth, allegedly by transmutation of mercury into gold, and founded and endowed fourteen hospitals in Paris, built three chapels, decorated and richly endowed seven churches and made many

Fig. 23 Portrait of Nicolas Flamel (1330-1418) famous for acquiring great wealth, allegedly by transmutation of mercury

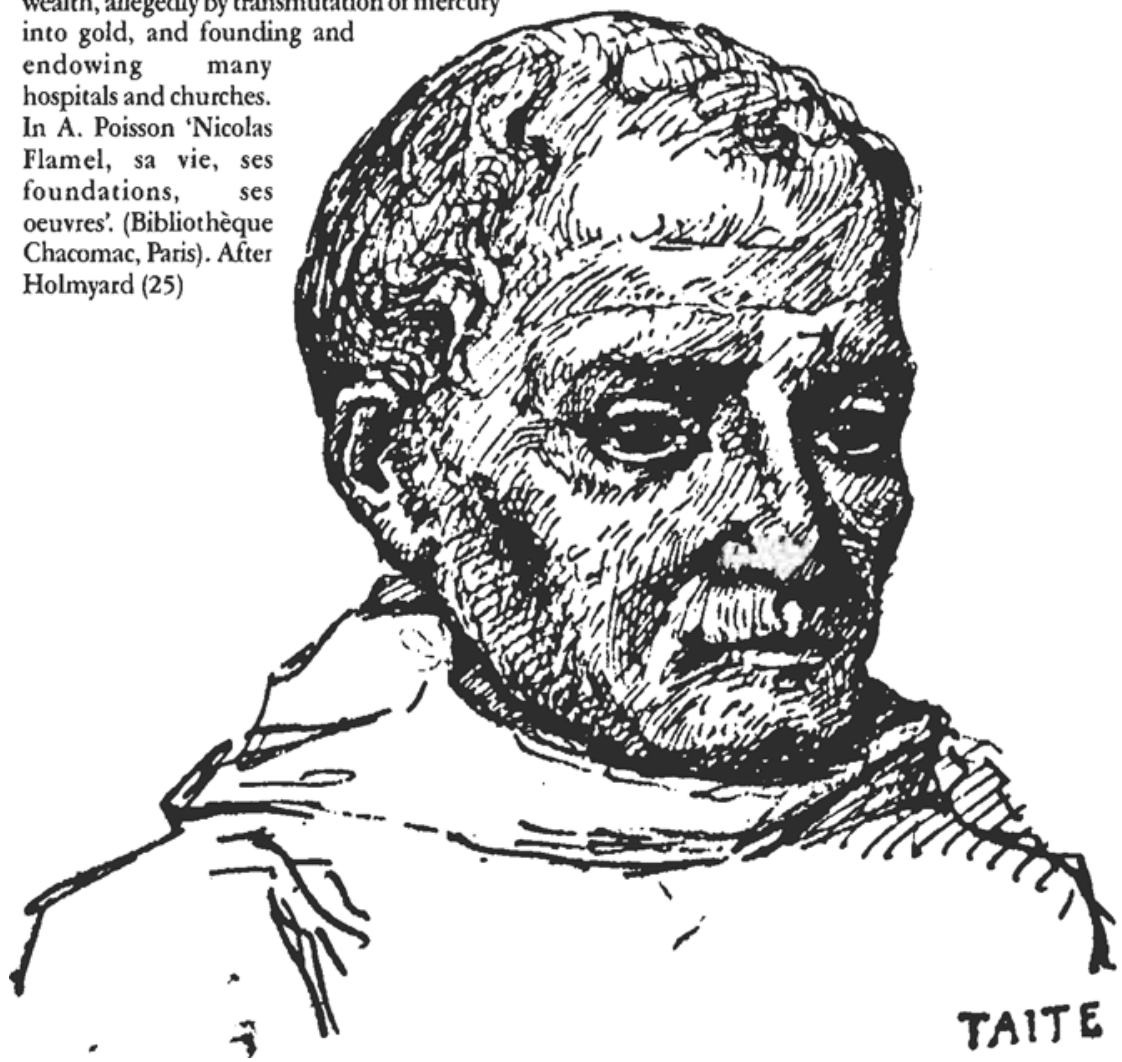

charitable gifts (Figures 23 and 24) (20, pp. 57-63;21, pp. 163-174; 23, pp. 6-24; 24, pp. 59-67; 25, pp. 233-242; 30, pp. 73-84; 32, pp. 40-51; 47, pp. 170-180; 68, pp. 123-128; 105, Chap. X; 107, p. 128; 111, pp. 47-54; 148, pp. 35-39).

4. Salomon Trismosin, ca. 1476 (20, pp. 82-87; 24, pp. 67-74).

5. Denis Zachaire, ca. 1546 (25, pp. 243-252;68, pp. 163-170; 105 , Chap. XIII).

6. John Dee (1527-1608) and Edward Kelly (1555-1597?)(20, pp. $116-128 ; 30$, pp. 109-118; 32, pp. 82-89; 68, pp. 170-184; 105 , Chap. XV; 112, pp. 67-69; 149).

7. Alexander Seton (?-1604), 1602 (20, pp. 131-140; 25, pp. $218-231 ; 32$, pp. 89-92; 68, pp. 184-186; 105, Chap. XVI; 145 , Chap. III; 148, pp. 69-70).

8. Michael Sendivogius, the Cosmopolite (1556-1636 or 1646), 1604 (Figure 25) (20, pp. 140-148; 25, pp. 226-231; 30, pp. 119-135; 32, pp. 92-94; 68, pp. 186-189; 111, p. 88; 112, pp. $70-72 ; 145$, Chap. IV).

9. Joan Baptista Van Helmont(1579-1644), 1618(20, pp. 226-228; 21 , pp. $174-179 ; 25$, pp. $253-261 ; 30$, pp. $137-139 ; 145$, pp. 66-68; 1'́s, pp. 45-46; 147, pp. 181-188).

10. Joharnes Friedrich Schweitzer, better known as Helvetius (1625-1709), who reported a transmutation of lead into gold by means of the philosopher's stone by a stranger named Elias in the Hague on December 27 th, 1666(20, pp. 157-164; 21, pp. 179-189; 30, pp. 140-147; 56, pp. 18-20; 105, Chap. XXII; 112, pp. 82-89; 145, pp. 67-78; 146, pp. 42-45; 147, pp. $183-188 ; 148$, pp. 54-58).

11. Robert Boyle (1627-1691), 1678 (20, pp. 165-168; 30, pp. 148-149; 147, pp. 188.192).

12. Comte de Saint Germain (?-1784), who claimed to have lived 2000 years (19, pp. 364-365;23, pp. 25-27; 30, Chap. $11 ; 68$, pp. $230-237 ; 148$, pp. $71-75$; $150)$.

13. Comte de Cagliostro (Giuseppe Balsamo) (Figure 26) (ca. 1743-1795) (20, pp. 259-264; 68, pp. 237-255; 112, pp. 91-93).

14. James Price, F.R.S. (1752-1783), 1782, who allegedly transmuted mercury into gold numerous times before many witnesses, but when the Royal Society was about to make an official examination of his process, he committed suicide by drinking prussic $\operatorname{acid}(20$, pp. 264-267; 25, pp. 261-264; 27, pp. $117-118,181 ; 146$, pp. 19-21; 
147. pp. 192-219).

15. Johann Semler, ca. 1786 (25, pp. $264-266 ; 147$, pp. 219-221).

16. C. Théodore Tiffereau, $1849(23, \mathrm{pp}$. $90-95 ; 67$ b, p. $238 ; 146$, pp. 49.52; 147 . pp. 221-224).

17. August Strindberg (1849-1912), Sweden's greatest writer (23, pp. 94-95; 67b, pp. 237-238; 151-153).

18. Stephen Henry Emmens, in 1897-1898 sold to the U.S. Assay Office in New York gold ingots, which he claimed to have made from silver by his so-called 'Argentaurum' process. (1; 20, p. 274; 67 b, p. $238 ; 147$, pp. 224-234; 152; 154).

Fig. 24 The alchemical instruments of Nicolas Flamel as depicted in 'Alchimie de Flamel' a 16th-century French manuscript. The 7 colours of the alchemical process are shown in the correct order at the top of the picture. After Powell (32)

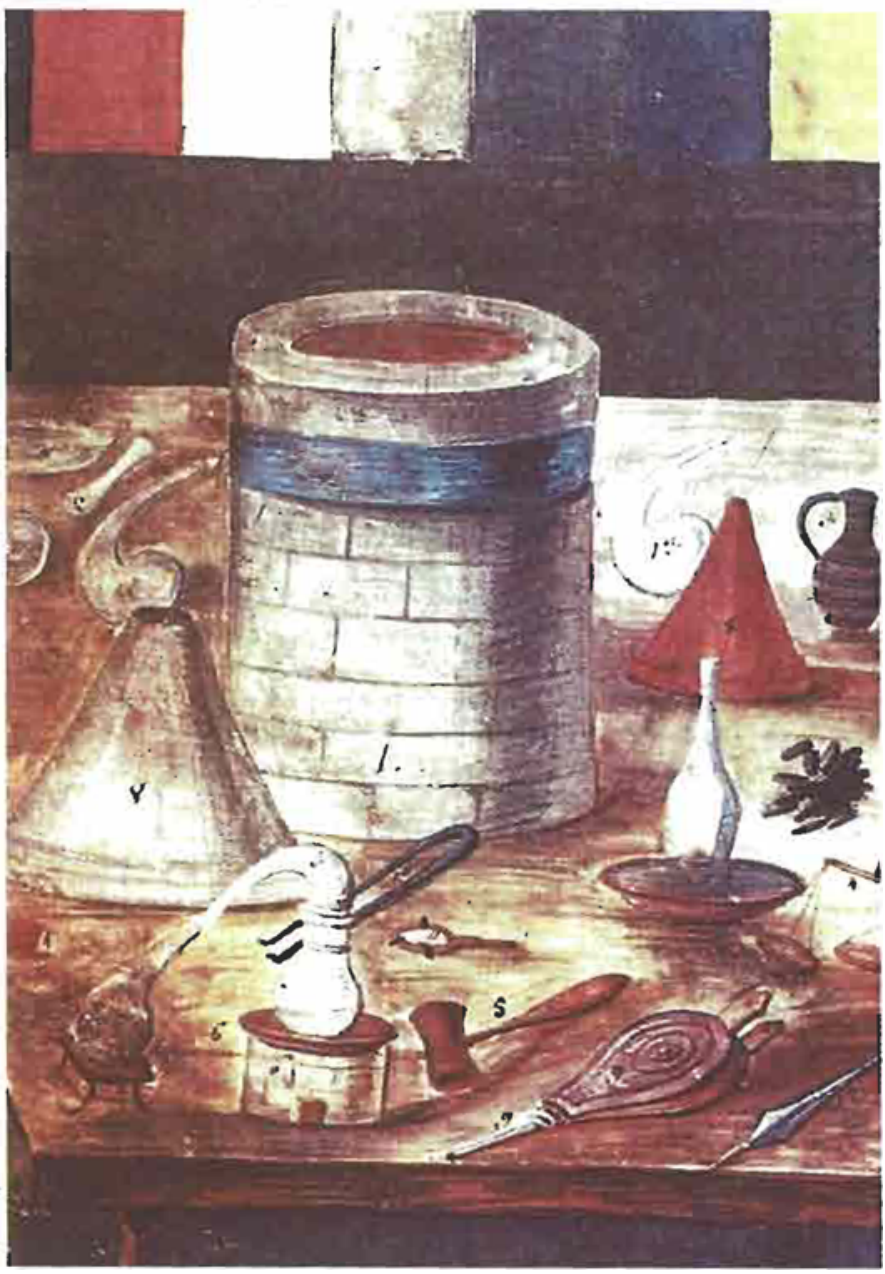

19. Franz Tausend, 1923 (20, pp. 278-286; 32, pp. 132-133).

20. Adolf Miethe, 1924 (23, pp. 184-185; 155, pp. 234-238)

21. Roman Dunikovski, 1931 (20, pp. 289-292; 32, pp. 133-134).

Fig. 25 Michael Sendivogius, the Cosmopolite, shown Imaking gold (1604) before a very attentive audience. From J. Sadoul 'Alchetnists and Gold' trs. O. Sieveking, Neville Spearman, London, 1972. After Powell (32)

Fig. 26 Compte de Cagliostro (Guiseppe Balsamo ca. 1743-1795. From 'Schauplatz der ausgearteten Menschheit'. After Federmann (28)

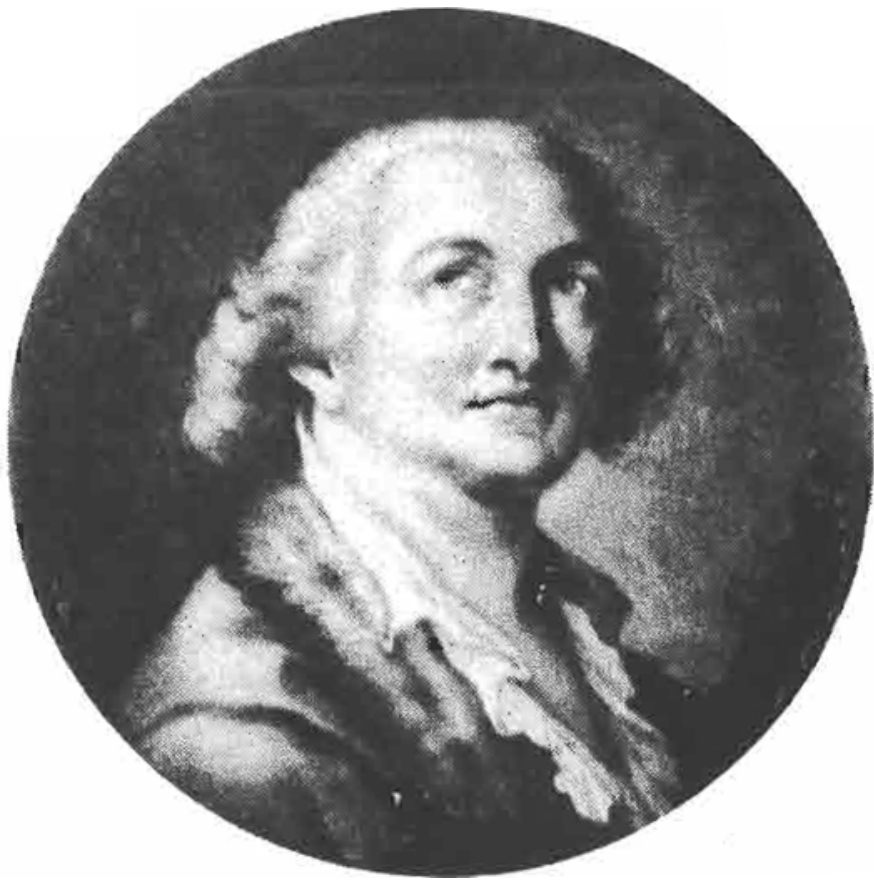




\section{References}

100 P. Ponsoy, 'L'Islam et le Graal', Denoël, Paris, 1958

101 L. Thorndike, 'History of Magic and Experimental Science', Vol, 2, Columbia University Press, New York, 1923, Chap. 68

102 M.A. Atwood, 'A Suggestive Inquiry into the Hermetic Mystery', 3 rdEd., W. Tait, Belfast, 1970, p. 72

103 S. Mahdihassan (Scientia, 1960,95, (2), 48-53; 1961, 96, (6), 187-195) claims that this so-called Serpent of Ouroboros was the probable origin of August Kekulé's dream of the benzene ring in 1865.

104 'A Treatise of the Names of the Philosophers Stone', collected by William Gratacolle, transl. into English by the Paines and Care of H.P., London, 1652 contains a list of more than 170 synonyms.

105 A.E. Waite, 'The Secret Tradition in Alchemy, Its Development and Record', Samuel Weiser, New York, 1969, Chap. XVIII

106 A.E. Waite (Editor), 'The Hermetic Museum, Restored and Enlarged', J. Elliott and Co., London, 1893, Vol. 2, p. 249

107 J. McCrae, The South African Industrial Chemist, 1950, 41, 102, 122

108 G.G. Scholem, 'Major Trends in Jewish Mysticism', Schocken Books, New York, 1941; 'On the Kabbalah and Its Symbolism', transl. by R. Manheim, Schocken Books, New York, 1969; L. Schaya, 'The Universal Meaning of the Kabbalah' George Allen and Unwin, Limited, London, 1971, Penguin Books, Baltimore, Maryland, 1973

109 E. Ashmole, 'Theatrum Chemicum Britannicum', J. Grismond, London, 1652, p. 350

110 M. Sendivogius, 'Novum Lumen Chemicum', Nuremberg, 1766

111 J. Read, "Through Alchemy to Chemistry; A Procession of Ideas and Personalities', G. Bell \& Sons, London, 1961, p. 70

112 H.S. Redgrove, 'Alchemy: Ancient and Modern', William Rider and Son London, 1922, pp. 35.36

113 T.L. Davis, Isis, 1932, 18, 213; Proc. Amer. Acad. Arts Sci., 1935, 70, 221

114 S. Trismosin, 'Splendor solis', with explanatory notes by J.K. [Julius Kohn?] Kegan Paul, London, n.d. [1920?], p. 79

115 R.S. Clymer, 'Alchemy and the Alchemists', Philosophical Publishing Co. Allentown, Pennsylvania, 1907; AMS Press, New York, 1980

116 L. Figuier, 'L'Alchimie et les Alchimistes', L. Hachette and Co., Paris, 1854

$116 \mathrm{a}$ J.A. Weishicpl(Editor), 'Albertus Magnus and the Sciences', Pontifical Institute of Mediaeval Studies, Toronto, 1980

117 'The Golden Calf, Which the World Adores, and Desires, ... faithfully Englished from the Latin of J.F. Helvetius', John Starkey, London, 1670, p. 45 et seq.

I18 (a) H. Kopp, 'Dic Alchemie in älterer und neucrer Zeit', C. Winter, Heidelberg, 1886, Vol. 2, p. 246; (b) MS. 'Philosophorum Praeclara Monita' (The Most Renowned Maxims of Philosophers) in the St. Andrews Collection, written in French and Latin, and based on works by George Ripley, Arnold of Villanova, Raymond Lully, Nicolas Flamel, Eirenacus Philalethes, Jean de Ré, and ochers. See 24, p. 47

119 S. Hutin, 'A History of Alchemy', transl. by T. Alferoff, Walker and Co., New York, 1962, pp. 30-33 gives a glossary of alchemical symbols

120 G.J. Higby, Gold Bull., 1982, 15, (4), 130-140 reviews the uses of gold in medicine and deals with potable gold in some detail

121 A. Walcy, Bulletin of the School of Oriental Siudies, Iondon Institution, 1930 6. part 1

122 R.N. Bhagvat, J. Chem Educ, 1933, 10,659-666

123 J. Needham, H. Ping-Yü and L. Gwei-Djen, 'Science and Civilisation in China', Vol. 5, Part 3, Cambridge University Press, New York, 1976, p. 144

124 W. Pagel, 'Paracejsus: An Introduction to Philosophical Medicine in the Era of the Renaissance', Karger, Basel and New York, 1958, p. 256

125 J. Ruska, 'Pseudo-Geber', in (63, pp. 60-69)

126 H. Kopp, 'Geschichte der Chemie', F. Vicweg und Sohn, Braunschweig, 1847 , reprinted in facsimile by Georg Olms Verlagsbuchhandlung, Hildesheim 1966, Vol. 3, pp. 348-353, Vol. 4, pp. $82-89$

127 'Fr. Basilii chymische Schriften', rev. edn., Part 1, Gotfried Liebezeit, Hamburg, 1658, pp. 281-282

128 L. Thorndike, in (101, p. 857)

129 'Von den Krankheiten, die der Vernunft berauben', in K. Sudhoff (Editor) 'Paracelsus: Sämtliche Werke', Vol. II, R. Oldenbourg, Munich, 1930, p. 452;
J. Starobinski, 'History of the Treatment of Melancholy', New York, 1972, p. 38 130 J. Garai, 'The Book of Symbols', Simon and Schuster, New York, 1973, pp. 18-19

131 A.E. Waite, 'The Hermetic and Alchemical Writings of ... Paracelsus', 2 vols, J. Elliotr and Co., London, 1894

132 'Aurum-potabile; or the receit of Dr. Fr. Anthonie', in [Various authors], 'Collectanea chymica: A collection of ten several treatises in chymistry, concerning the Liquor Alkahest, the Mercury of the Philosophers, and other curiosities worchy the perusal', William Cooper, London, 1684; also reprinted in (115, pp. 25-35)

133 J.R. Glauber, 'The Works of the Highly Experienced and Famous Chymist, John Rudolph Glauber ..., trans!. by C. Packe, Thomas Milbourne, London, 1689

134 E. Darmstacdter, Chem,-Ztg., 1924, 48,653,678

135 R. Burton, 'The Anatomy of Melancholy', edited by F. Dell and P. JordanSmith, Tudor Publishing Co., New York, 1951, pp. 395, 569, 573, 577, 588

136 H. Lösner, Kolloid-Zeitschrift, 1910, 6, 1-3

137 W. Lewis, 'A Course of Practical Chemistry', J. Nourse, London, 1746, pp. 19-22, 415-422 gives George Wilson's recipe for aurum potabile

138 N. Lémery, 'A Course of Chymistry', Walter Kettilby, London, 1686, pp, 48.61

139 É.-F. Geoffroy, 'A Treatise of the Fossil, Vegetable and Animal Substances That Are Made Use of in Physick', W. Innys, R. Manby et ah., London, 1736, pp. $267-270,281$

140 S. Mahdihassan, Jamus, 1971, 58, (1), 112-118

141 A. Cornejo, Kolloid-Zeitschrijt, 1913, 12, 1.6

142 A. Libavii, 'Praxis alchymiae', Excudebat Joannes Saurius, impensis Petri Kopfii, Francofurti, 1604, pp. 586-587

143 W.P. Jorissen and J. Postma, Chem. Weekblad, 1927, 24, 30-33

144 R. Zsigmondy, Z. and. Chem., 1901, 40,697 gives directions for the preparation of colloidal gold. H. Biltz and W. Biltz, 'Laboratory Methods of Inorganic Chemistry', transl. by W.T. Hall and A.A. Blanchard, John Wiley and Sons, New York, 1928, pp. 47-49 gives directions for the preparation of colloidal gold and purple of Cassius

145 J. Read, 'Humour and Humanism in Chemistry', G. Bell and Sons, London, 1947, pp. 92-101

146 S.H. Emmens, 'Argentaurana or Some Contributions to the History of Science', Geo. Du Boistel and Co., Bristol and London, 1899

147 R.T. Gould, 'Enigmas: Another Book of Unexplained Facts', Paperback Library, New York, 1969 , pp. 174.238

148 A. Cockren, 'Alchemy Rediscovered and Restored', David McKay Co., Philadelphia, 1940

149 R. Deacon, 'John Dee', Muller, London, 1968; P.J. French, 'John Dee: The World of an Elizabethan Magus', Routledge and Kegan Paul, London, 1972

150 P. Chacornac, 'Le comte de Saint-Germain', Chacornac Frères, Paris, 1947; M. Heim, 'Le vrai visage de comte de Saint-Germain', Gallimard, Paris, 1958; I. Cooper-Oakley, 'The comte de St. Germain: The Secret of Kings', Samucl Weiser, New York, 1970; P. Sevran, 'Le Comte de Saint Germain, Aujourd'hui', Nouvel Office d'Éditions, Paris, 1973: G.B. Kauffman and R.J. Broughten, The Hexagon, 1979, 70, (1), 20-22; Rev. Chil. Educ. Ouim., 1979, 4, (5). 230-233

151 A. Strindberg, 'Antibarbarus eller verlden för sig och verlden för mig', transl into German by B. Lidforss as 'Antibarbarus I oder die Welt für sich und die Welt für mich:, Verlag des Bibliographischen Bureaus, Berlin, 1894 L'Hyperchimie, 1896, 1, (4), 1-3; 'The Inferno', transl. by C. Field, G.P. Putnam's Sons, New York, 1913

152 H. Bolton, Science, 1897, 6, 853-863, reprinted in Ann. Rep. BoardofRegents Smithsonian Institution for 1897, 1898, 207-217; 'Hysterical Chemistry', E.J Davey, London, 1898, reprinted from Chem. News, 1898, 77, 3-5, 16-18; Chem. News, 1898, 77, 69-70, 73-74

153 (a) T. Svedberg, Formm, 1918, 5, (4), 44-47, reprinted in 'Forskning och industri: Naturvetenskapliga Essayer', Hugo Gebers Förlag, Srockholm, 1918, pp. 76-100 (b) G. Brandell, 'Strindberg in Inferno', transl. by B. Jacobs, Harvard University Press, Cambridge, Massachussetrs, 1974; (c) G.B. Kauffman, J. Chem. Educ., 1983,60, 584-590; (d) G.B. Kauffman, Industrial Chemical News, Sept., 1984 5, (9), 26-cover 3

154 G.B. Kauffman, Ambix, 1983, 30, 65-88; Endeavour, 1983, 7, 150-154 